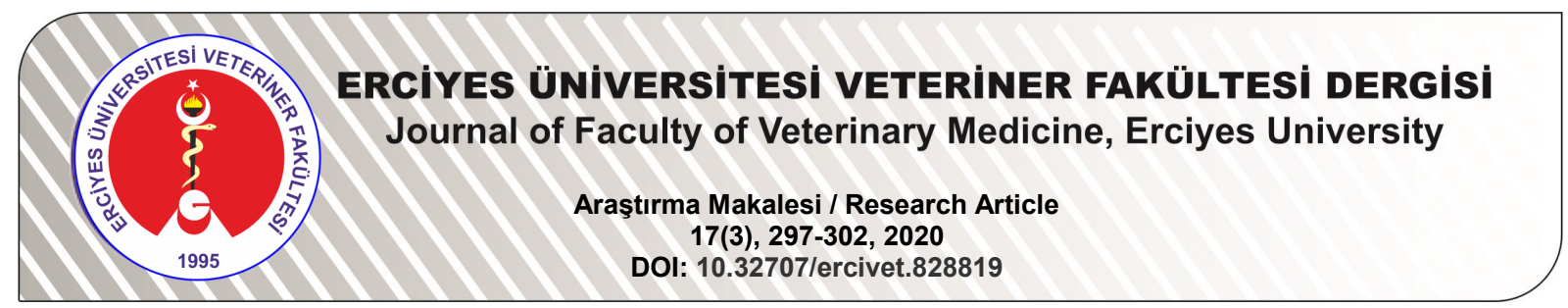

\title{
İnkübasyon Çıkış Asitliğinin Geleneksel Olarak Üretilen Süzme Yoğurtların Bazı Kalite Özellikleri
} Üzerine Etkisi

\author{
Engin YARALI, Şevki ÇETINER
}

Aydın Adnan Menderes Üniversitesi, Çine Meslek Yüksekokulu, Aydın-TÜRKIYE

Sorumlu yazar: Engin YARALI; E-posta: eyarali@adu.edu.tr; ORCID: 0000-0003-1525-0371

Atıf yapmak için: Yaralı E, Çetiner Ş. İnkübasyon çıkış asitliğinin geleneksel olarak üretilen süzme yoğurtların bazı kalite özellikleri üzerine etkisi. Erciyes Üniv Vet Fak Derg 2020; 17(3): 297-302.

Özet: Araştırmanın amacı, inek sütüne $85^{\circ} \mathrm{C}$ 'de ısıl işlem uygulayarak, bu sütlerden geleneksel yolla elde edilen süzme yoğurtların bazı kalite özellikleri üzerine, taze yoğurt inkübasyonu sonlandırma asitliğinin $(\mathrm{pH})$ etkisini araştırmaktır. İşletmeye gelen çiğ sütlerde, $\mathrm{pH}$, laktik asit cinsinden titrasyon asitliği ( $\left.{ }^{\circ} \mathrm{SH}\right)$, \% yağ, \% toplam kuru madde (KM) ve renk değerleri $\left(L^{*}, a^{*}, b^{*}, c, H\right)$ belirlenmiştir. Üretilen deneme süzme yoğurt örneklerinde toplam KM (\%), yağ $(\%)$, renk, $\mathrm{pH}$ ve randıman (\%) değerleri ölçülmüştür. Çalışmada yoğurt inkübasyon süreleri, inkübasyon sonlandırma pH'sına $(4.40,4.20 .4 .00)$ göre sırasıyla $279.33,368.33$ ve 788.07 dakika olarak ölçülmüştür. Süzme yoğurtta randıman değerleri sırasıyla \% 34.47, \% 33.40 ve \% 29.57 olarak hesaplanmıştır. Süzme yoğurtta KM oranları sırasıyla \% 24.30 , $\% 23.25, \% 24.60$ ve yağ oranları sırasıyla \% 9.69, \% 10.47 ve \% 10.67 olarak tespit edilmiştir. İnkübasyon çıkıs pH'sının bu anlamda süzme yoğurt örneklerinde $K M$ ve yağ üzerine etkisi istatistiki olarak önemsiz bulunurken $(P>0.05)$, randıman $(P<0.05)$ ve yoğurt inkübasyon süresi $(P<0.01)$ üzerine etkisi istatiksel olarak önemli bulunmuştur $(P<0.01)$. Süzme yoğurtlarda yapılan renk ölçümlerinde, ortalama $L^{*}$ değeri 94.44 , a* değeri $-1.66, b^{*}$ değeri $9.43, c$ değeri 9.60 ve H değeri 100.14 olarak ölçülmüştür. Sonuç olarak, yoğurt üretiminde inkübasyon pH'sının 4.40 veya 4.20 olarak ayarlanması ve inkübasyonun bu şeklide bitirilmesi işletmeler için daha ekonomik ve avantajlı olacaktır.

Anahtar kelimeler: İnkübasyon, kimyasal özellik, süzme yoğurt

The Effect of Incubation Exit Acidity on Some Quality Properties of Traditionally Produced Strained Yoghurt Summary: The aim of the research is to investigate the effect of fresh yogurt incubation finishing acidity $(\mathrm{pH})$ on some quality properties of traditional strained yogurt obtained from this milk by applying heat treatment at $85^{\circ} \mathrm{C} . \mathrm{pH},{ }^{\circ} \mathrm{SH}, \mathrm{fat}$ $(\%)$ dry matter $(\%)$ and color values $\left(L^{*}, a^{*}, b^{*}, c, H\right)$ were determined in raw milk. Total dry matter $(\%)$, fat $(\%)$, color, $\mathrm{pH}$ and production yield (\%) were measured in the samples of trial strained yogurt produced. In the study, yogurt incubation times were recorded as $279.33,368.33$ and 788.07 minutes, respectively, according to incubation finishing $\mathrm{pH}$ $(4.40,4.20 .4 .00)$. The yields of the strained yoghurt were calculated as $34.47 \%, 33.40 \%$ and $29.57 \%$, respectively, according to the incubation output $\mathrm{pH}$. The dry matters in strained yoghurt were identified as $24.30 \%, 23.25 \%, 24.60 \%$, and fat ratios were $9.69 \%, 10.47 \%$ and $10.67 \%$, respectively. In this sense, while the effect of incubation outlet $\mathrm{pH}$ on dry matter\% and fat\% in strained yogurt samples was found to be statistically insignificant $(P>0.05)$, the effect on efficiency $(P<0.05)$ and yoghurt incubation time $(P<0.01)$ was very important. In color measurements made in strained yogurt, the mean $L^{*}$ value was $94.44, a$ * value was $-1.66, b$ * value was $9.43, c$ value was 9.60 and $H$ value was 100.14. As a result, it will be more economical and advantageous for businesses to adjust the incubation $\mathrm{pH}$ to 4.40 or 4.20 and to complete the incubation in this way in yoghurt production.

Key words: Chemical properties, incubation, strained yoghurt

\section{Giriş}

Sütün laktik asit fermantasyonu yöntemi ile işlenerek yoğurda dönüştürülmesi oldukça eski bir yöntemdir. Ancak bu üründe su oranının yüksek olması ve bakteri faaliyetlerinden dolayı raf ömrü sınırlıdır. Bu nedenle su oranının azaltılarak konsantre yoğurt elde etmek ülkemizde ve çeşitli ülkelerde kullanılan bir yöntemdir (Atamer ve ark., 1988). Ülkemizde çiğ süt üretimi 2018 yılında 22.120.716 ton olarak hesaplan-

Geliş Tarihi/Submission Date : 13.07.2020 Kabul Tarihi/Accepted Date : 12.10 .2020 mıştır. Yoğurt üretimi 2018 yılında bir önceki yıla göre \%2.2 oranında artarak 1.19 milyon ton olmuştur. Kişi başına yoğurt tüketimi ise $30.6 \mathrm{~kg}$ olarak hesaplanmıştır (Anonim, 2018). Konsantre yoğurt ülkemizde "Torba Yoğurt" veya "Süzme Yoğurt" olarak ifade edilmektedir (Eralp, 1953; Yaygın, 1999; Terin ve Yavuz, 2015). Süzme yoğurt yumuşak ve kolay sürülebilen bir yapıda olup kuru madde oranı yüksektir. Protein yönünden zengin olan süzme yoğurtlarda renk, kullanılan süt türüne göre beyazdan sarıya değişmektedir. Ürün kendisine has tada, koku ve yapıya sahiptir. İsteğe göre yağ oranı farklı yoğurtlardan (inek, koyun, keçi ve manda sütlerinden) üretilebil- 
mektedir. Süzme yoğurdun randımanı \%20-30 arasında değişmektedir (Demirci ve Gündüz, 2000).

Süzme yoğurt üretiminde geleneksel olarak uygulanan metot uzun zaman almakta ve hijyenik koşulların sağlanmasında güçlükler ortaya çıkmaktadır. Bu yöntemde taze yoğurt elde edildikten sonra 24 saat buzdolabı sıcaklığında bekletilip bez torbalara aktarımakta ve $12-24$ saat süre ile süzülmeye bırakılmaktadır. Elde edilen ürünün kalitesi ise kullanılan hammaddeye, kültür tipi ve oranına, üretim metoduna ve hijyenik koşullara göre değişim göstermektedir (Atamer ve ark., 1988; Becker ve Puhan, 1989).

Ülkemizde, geleneksel bir ürün olan süzme yoğurt üretimi üzerine yapılan çalışmaların sayısı gün geçtikçe artmaktadır. Bu araştırmada amaç, sabit ısıl işlem uygulanmış çiğ sütlerden elde edilen taze yoğurtlarda farklı inkübasyon çıkış asitliğinin, bu yoğurtlardan geleneksel yolla üretilen süzme yoğurdun bazı kalite özellikleri üzerine etkisini araştırmaktır.

\section{Gereç ve Yöntem}

Çalışmada hammadde olarak kullanılan çiğ inek sütü, Aydın-Çine ilçesinde faaliyet gösteren süt üreticisinden temin edilmiştir. Araştırmada elde edilen süzme yoğurtlar bu araştırma için üretilmiştir. İşletmeye gelen çiğ sütlerin Türk Gıda Kodeksi İçme Sütleri Tebliği' ne uygun kriterlere sahip olduğu belirlenmiştir (Anonim, 2019). Araştırma Kasım 2019 tarihinde başlamış ve 9 hafta devam etmiştir. Her parti çiğ sütten TS EN ISO 707-Süt ve Süt Ürünleri-Numune Alma Kılavuzu' na (Anonim, 2009a) göre partiyi temsil edecek miktarda süt alınarak analizler gerçekleştirilmiştir. Çiğ süt numunelerinde yapılan tüm ölçümler 3 tekerrür olarak gerçekleştirilmiştir. Alınan çiğ sütlerde ortalama $\mathrm{KM}$ oranı $\% 11.70$, ortalama $\mathrm{SH}$ değer 7.11 , ortalama $\mathrm{pH}$ değeri 6.72 ve ortalama yağ oranı \% 3.72 olarak ölçülmüştür.

Ölçümleri yapılan sütlere çift cidarlı kazanda buhar ile ısıl işlem uygulanmıştır. Gelen sütler pişirme kazanına alınmış ve sıcaklık $85^{\circ} \mathrm{C}$ ye ulaştığında ısıl işlem sonlandırılmıştır. Isıl işlemi tamamlayan süt aynı kazanda eşanjör plakalı ısı değiştirici ile $48{ }^{\circ} \mathrm{C}$ 'ye soğutulmuş ve aynı kazanda liyofilize yoğurt kültürü (Jointec VH712, İtalya), inoküle edilmiştir. Çalışmada ticari kültür oranı \%60 Lactobacillus bulgaricus ve \% 40 Streptecoccus thermophilus olacak şekilde kullanılmış ve ilave edilecek kültür miktarı $\% 2$ olarak belirlenmiştir. Kültür ilavesinden sonra pişirme kazanından inkübasyon dolabındaki çelik gügüülere gıda hortumu ile aktarılan inoküle edilmiş süt, inkübasyona bırakılmıştır. İnkübasyon sıcaklığı $45-46{ }^{\circ} \mathrm{C}$ ' ye ayarlanmış ve inkübasyonunun sonlandırılması pH kontrolü ile yapılmıştır. Bunun için inkübasyon dolabına yerleştirilen inoküle edilmiş süt numunesine $\mathrm{pH}$ metre cihazının probu yerleştirilmiş ve asitlik dolap açılmadan takip edilmiştir. Ölçülen $\mathrm{pH}$ değeri ilk üç hafta alınan sütlerden elde edilen taze yoğurtlarda 4.40 , ikinci üç haftalık dönemde alınan sütlerden elde edilen taze yoğurtlarda 4.20 ve son üç haftalık periyotta alınan sütlerden elde edilen taze yoğurtlarda 4.00 değerine geldiğinde inkübasyon işlemi sonlandırılmıştır. İnkübasyonunu tamamlamış ürün bekletilmeden $10{ }^{\circ} \mathrm{C}$ ' nin altında çalışan buzdolabına alınarak 12 saat süre ile soğumaya bırakılmıştır. Soğutma işleminden sonra gügümlerdeki ürün, süzme bezlerine aktarılarak 24 saat boyunca süzülmesi sağlanmış ve süre sonunda elde edilen süzme yoğurt tartılarak toplam miktarı $(\mathrm{kg})$ belirlenmiştir.

Yoğurt örneklerinin KM (\%), titrasyon asitliği (\% laktik asit), yağ (\%), Soxhlet-Henkel ( $\left.{ }^{\circ} \mathrm{SH}\right)$ ve $\mathrm{pH}$ analizleri Metin (2012) tarafından belirlenen yöntemlere göre yapılmıştır. Kuru madde tayini için RADWAG MA 50R marka halojen nem tayin cihazı, $\mathrm{pH}$ ölçümü için kalibre edilmiş MILWAUKEE MW 102 marka pH metre cihazı kullanılmıştır. Renk analizi 3NH TECHNOLOGIES NR200 model kolorimetre cihazı kullanılarak gerçekleştirilmiştir. Bunun için alınan süt numunesi cihazın sıvı kiti için hazırlanan bölmesine aktarılmış ve renk ölçümleri gerçekleştirilmiştir.

Süzme yoğurt numunelerdeki KM oranı halojen nem tayin cihazı kullanılarak tespit edilmiştir. Cihazın kalibrasyonu ve ayarları yapıldıktan sonra cihazın uygun bölmesine yerleştirilen süzme yoğurt örneğinde sonuç cihazın ekranından okunmuştur. Asitlik ölçümünde $\mathrm{pH}$ metre cihazı kullanılmış ve cihazın $\mathrm{pH}$ : 4.00 ve pH: 7.00 tampon çözeltiler ile kalibrasyonu yapıldıktan sonra uygun probu ürün numunesine daldırılmış ve cihazdan $\mathrm{pH}$ değeri okunmuştur. Örneklerin ölçüm sıcaklığı 13-14 ${ }^{\circ} \mathrm{C}^{\prime}$ dir.

Süzme yoğurt örneklerinde yapılan yağ tayini için gerber metodu kullanılmıştır. Bunun için yağ bütirometresinin içerisine $10 \mathrm{ml} \mathrm{H}_{2} \mathrm{SO}_{4}, 11 \mathrm{ml} \frac{1}{4}$ oranında sulandırılmış süzme yoğurt ve $1 \mathrm{ml}$ amil alkol koyulmuş ve aletin tıpası kapatılmıştır. Bütirometre alt üst edilerek asidin numuneyi yakması sağlanmış ve bu işleme renk tamamen kahverengiye dönene kadar devam edilmiştir. Daha sonra bütirometre 1200 devir/ dakika hızla çalışan santrifüjde 5 dakika santrifüj edilmiştir. Okuma yapmadan önce $65-70{ }^{\circ} \mathrm{C}$ ' de bekletilen tüpün skalasından okuma yapılmış ve sonuç 4 ile çarpılmıştır. Süzme yoğurt örneğinde renk tayini için renk ölçer cihazı kullanılmış ve cihazın okuma bölgesi süzme yoğurt numunesi üzerine getirilerek $L^{*}$ (parlaklık), a* (kırmızılık), b* (sarıık), c ve H değerleri okunarak kaydedilmiştir. Süzme yoğurttaki tüm ölçümler 3 tekerrür şeklinde yapılmış ve ölçüm sonuçIarının ortalaması ve standart hataları alınmıştır. Elde edilen veriler kaydedilerek sonuçlar istatistik olarak PASW Statistics 18 programında değerlendirilmiştir. 


\section{Bulgular}

Tablo 1. Çiğ sütün bazı fizikokimyasal özellikleri

\begin{tabular}{|c|c|c|c|}
\hline \multicolumn{4}{|l|}{ Özellikler } \\
\hline İnkübasyon çıkış pH & 4.40 & 4.20 & 4.00 \\
\hline Toplam çiğ süt miktarı (kg) & 571.00 & 555.00 & 589.00 \\
\hline Çiğ süt pişirme süresi ort. (dak.) & 27.07 & 24.00 & 17.00 \\
\hline Çiğ süt KM oranı ort.(\%) & 11.65 & 11.90 & 11.56 \\
\hline Çiğ süt SH değeri ort. & 6.80 & 7.59 & 6.93 \\
\hline Çiğ süt pH değeri ort. & 6.66 & 6.75 & 6.75 \\
\hline Çiğ süt yağ oranı ort.(\%) & 3.85 & 3.76 & 3.54 \\
\hline \multicolumn{4}{|l|}{ Çiğ sütte renk ölçümleri (ort.) } \\
\hline $\mathrm{L}^{*}$ & 84.47 & 58.06 & 60.74 \\
\hline$a^{*}$ & -2.68 & -0.90 & -0.79 \\
\hline$b^{*}$ & 4.05 & 7.37 & 7.41 \\
\hline c & 4.60 & 7.42 & 7.44 \\
\hline $\mathrm{H}$ & 115.88 & 96.80 & 96.12 \\
\hline \multicolumn{4}{|c|}{ Isıl işlem görmüş sütte renk ölçümleri (ort.) } \\
\hline $\mathrm{L}_{\text {e }}$ & 76.89 & 58.72 & 61.03 \\
\hline$a^{*}$ & -3.41 & -1.71 & -1.48 \\
\hline$b^{*}$ & 3.78 & 6.81 & 7.11 \\
\hline C & 5.27 & 7.02 & 7.22 \\
\hline $\mathrm{H}$ & 133.40 & 104.10 & 101.75 \\
\hline İnkübasyon sıcaklığı ( C) & 46 & 46 & 46 \\
\hline Toplam serum miktarı $(\mathrm{kg})$ & 375.98 & 370.59 & 414.74 \\
\hline Toplam süzme yoğurt miktarı $(\mathrm{kg})$ & 195.02 & 184.41 & 174.26 \\
\hline
\end{tabular}

$L^{*}$ :Parlaklık, a*:kırmızılık, b*:sarılık, c:kroma, H:açı

Araştırmada belirlenen değerlere ait istatistik sonuçları Tablo 1' de verilmiştir. İnkübasyon çıkış pH'sının, inkübasyon süresi ile elde edilen süzme yoğurtların randıman, KM, yağ ve renk değerleri üzerine etkisi Tablo 2' de verilmiştir. Araştırmada elde edilen veriler ele alındığında, süzme yoğurtta randıman değerleri inkübasyon çıkış pH'sına $(4.40,4.20 .4 .00)$ göre sırasıyla \%34.47, \%33.40 ve \%29.57 olarak hesaplanmıştır. Süzme yoğurtta 3 tekerrürlü ölçümlerde ortalama yağsız KM oranları inkübasyon çıkış pH'sına göre sırasıyla $\% 24.30 \pm 2.45, \quad \% 23.25 \pm 1.27$ ve $\%$ $24.60 \pm 0.91$, ortalama yağ oranları sırasıyla \% $9.69 \pm 0.78, \% 10.47 \pm 0.81$ ve $\% 10.67 \pm 0.93$ ve ortalama $\mathrm{pH}$ değerleri sırasıyla $3.83 \pm 0.03,3.84 \pm 0.04$ ve $3.97 \pm 0.17$ 'dir. Yoğurt inkübasyon süreleri dakika olarak sırasıyla $279.33 \pm 29.56, \quad 368.33 \pm 70.24$ ve $788.07 \pm 143.64$ olarak belirlenmiştir. İnkübasyon çıkış $\mathrm{pH}$ 'sının bu anlamda süzme yoğurt $\mathrm{KM}$, yağ ve $\mathrm{pH}$ üzerine etkisi önemsiz bulunurken, randıman $(P<0.05)$ ve yoğurt inkübasyon süresi $(P<0.01)$ üzeri-

Tablo 2. İnkübasyon çıkış pH'sının inkübasyon süresi, süzme yoğurt randıman, kuru madde, yağ ve renk üzerine istatistiki etkisi

\begin{tabular}{lcccc}
\hline Özellikler & $\mathbf{p H : 4 . 4 0}$ & $\mathbf{p H : 4 . 2 0}$ & $\mathbf{p H : 4 . 0 0}$ & Ortalama \\
\hline INKS (dak.) & $279.33 \pm 29.56^{* *}$ & $368.33 \pm 70.24^{* *}$ & $788.07 \pm 143.64^{* *}$ & $478.44 \pm 248.75$ \\
SYR (\%) & $34.47 \pm 1.68^{*}$ & $33.40 \pm 2.43$ & $29.57 \pm 2.58^{*}$ & $32.48 \pm 2.97$ \\
SYKM (\%) & $24.30 \pm 2.45$ & $23.25 \pm 1.27$ & $24.60 \pm 0.91$ & $24.04 \pm 1.58$ \\
SYY (\%) & $9.69 \pm 0.78$ & $10.47 \pm 0.81$ & $10.67 \pm 0.93$ & $10.27 \pm 0.86$ \\
SYpHb & $3.84 \pm 0.05$ & $3.98 \pm 0.08$ & $3.94 \pm 0.04$ & $3.92 \pm 0.08$ \\
SYpH & $3.83 \pm 0.03$ & $3.84 \pm 0.04$ & $3.97 \pm 0.17$ & $3.88 \pm 0.11$ \\
L $^{*}$ & $94.83 \pm 1.57$ & $94.79 \pm 0.17$ & $93.70 \pm 0.47$ & $94.44 \pm 0.99$ \\
a $^{*}$ & $-2.02 \pm 0.68$ & $-1.93 \pm 0.14$ & $-1.03 \pm 0.28$ & $-1.66 \pm 0.60$ \\
b $_{\text {C }}$ & $8.83 \pm 1.05$ & $9.39 \pm 0.15$ & $10.08 \pm 0.54$ & $9.43 \pm 0.81$ \\
H & $9.08 \pm 1.08$ & $9.59 \pm 1.73$ & $10.54 \pm 0.12$ & $9.60 \pm 0.56$ \\
\hline
\end{tabular}

${ }^{*} \mathrm{P}<0.05 ;{ }^{* *} \mathrm{P}<0.01 ;{ }^{* *} \mathrm{P}<0.001$. INKS: Süt inkübasyon süresi. SYR: Süzme yoğurt randıman. SYKM: Süzme yoğurt KM. SYY: Süzme yoğurt yağ. SKM: Çiğ süt KM. SYpH: Süzme yoğurt pH. SYpHb: Süzme yoğurt buzdolabı çıkış pH 
ne etkisi ise istatistiki olarak önemli bulunmuştur. İnkübasyon çıkış pH'sının 4.00' a düşürülmesi özelikle randımanda azalmaya, elde edilen süzme yoğurt suyunda artışa ve inkübasyon süresinin uzamasına sebep olduğu ortaya konulmuştur. Süzme yoğurt örneklerinde üretimin çıkış pH sına göre aynı anda yapılamaması ve partiler arası üretimin uzun sürmesi nedeniyle duyusal analizler yapılamamıştır.

Süzme yoğurtta yapılan renk ölçümlerinde, ortalama olarak $L^{*}$ değeri $94.44 \pm 0.99$, a* değeri $-1.66 \pm 0.60, b^{*}$ değeri $9.43 \pm 0.81$, c değeri $9.60 \pm 0.56$ ve $H$ değeri $100.14 \pm 3.89$ olarak ölçülmüştür. İnkübasyon çıkış pH değerinin sadece $\mathrm{H}$ değeri üzerine etkisi istatistiki olarak önemlidir $(P<0.05)$. Araştırmada süzme yoğurtlarda $L^{*}$ ve $b^{*}$ değerinde yüksek değerler belirlenmiştir. Yapılan bu çalışmada, çiğ ve ısıl işlem görmüş sütte yapılan renk ölçümleri sonucunda tespit edilen değerler arasında önemli derecede pozitif ve negatif korelasyonlar saptanmıştır (Tablo 3). (açı) ise renk canlılığını ifade etmektedir (Keskin ve ark., 2017, Xrite, 2007). Çiğ sütün ısıl işlem görmesi ile sütteki bileşenler (laktoz ve proteinler) etkilenmekte ve doğal olarak süt ve yoğurdun renginde değişiklikler meydana gelmektedir. Burdur ilinde süzme yoğurt üretim teknolojisine yönelik olarak yapılan bir çalışmada, dört farklı işletmeden alınan süt numunelerinde ortalama olarak KM oranı \%11.31 ve SH 6.89 olarak hesaplarken bu sütlerden üretilen süzme yoğurtlarda toplam KM \%21.90, yağ \%5.53, pH 3.69 ve SH 79.98 olarak bulunmuştur. İşletmede çiğ sütlere $85^{\circ} \mathrm{C}$ de $15-20$ dak. ve $95^{\circ} \mathrm{C}$ de $20 \mathrm{dk}$. Isıl işlem uygulanırken, inkibasyon kış aylarında $36-50{ }^{\circ} \mathrm{C}$ de, yaz aylarında $43-50{ }^{\circ} \mathrm{C}$ de gerçekleştirilmiştir (Kırdar ve Gün, 2001). Yapılan başka bir araştırmada, Denizli satılan süzme yoğurtlardan 57 örnek alınmış ve bunların bazı kimyasal ve mikrobiyolojik özellikleri belirlenmiştir. Araştırmada yaz ve kış sezonu torba yoğurtlarının KM içeriğinin \%14.00 ile \%31.67 arasında değiştiği görülmüştür. Aynı yoğurtlarda titrasyon asitliği \%1.37 ile \%2.41 arasında, yağ değeri \%4.00-\%

Tablo 3. Çiğ süt ve ısıl işlem görmüş sütte renk parametreleri arasındaki korelasyonlar

\begin{tabular}{lccccc}
\hline & \multicolumn{5}{c}{ Isıl Işlem Görmüş Süt } \\
\hline & $\mathbf{L}^{*}$ & $\mathbf{a}^{*}$ & $\mathbf{b}^{*}$ & $\mathbf{C}$ & $\mathbf{H}$ \\
\hline Çiğ Süt $\mathrm{L}$ & $0.910^{* *}$ & $-0.902^{* *}$ & $-0.941^{* *}$ & $-0.929^{* *}$ & $0.955^{* *}$ \\
Çiğ süt $\mathbf{a}^{*}$ & $-0.874^{* *}$ & $0.940^{* *}$ & $0.985^{* *}$ & $0.979^{* *}$ & $-0.984^{* *}$ \\
Çiğ süt $b^{*}$ & $-0.872^{* *}$ & $0.939^{* *}$ & $0.975^{* *}$ & $0.973^{* *}$ & $-0.970^{* *}$ \\
Çiğ süt $\mathrm{C}$ & $-0.833^{* *}$ & $0.909^{* *}$ & $0.979^{* *}$ & $0.974^{* *}$ & $-0.968^{* *}$ \\
Çiğ süt $\mathrm{H}$ & $0.852^{* *}$ & $-0.886^{* *}$ & $-0.781^{*}$ & $-0.791^{*}$ & $0.801^{* *}$ \\
\hline
\end{tabular}

${ }^{*} \mathrm{P}<0.05 ;{ }^{* *} \mathrm{P}<0.01 ;{ }^{* * *} \mathrm{P}<0.001 . \mathrm{L}^{*}$ : Parlaklık değeri, $\mathrm{a}^{*}$ : kırmızılık değeri, $b^{*}$ : sarılık değeri

\section{Tartışma ve Sonuç}

Araştırmada inkübasyon çıkış pH'sının 4.40 ve 4.20 olacak şekilde sonlandırılması, süzme yoğurdun özellikleri ve randımanı üzerine etkili olmazken, pH'nın 4.00'a düşürülmesi elde edilen süzme yoğurt suyunda artışa ve doğal olarak randımanda düşüşe sebep olmuştur. Bu olay pH'nın etkisinden kaynaklanmaktadır. Çünkü proteinlerin su tutma kapasitesinde asitlik önemli bir parametredir. Asitlik düzeyi, ürünün yapısında ve serum ayrılmasında etkili bir faktördür. Düşük asitlikte proteinlerin su tutma kapasiteleri yetersizken, yüksek asitlikte söz konusu özellikte azalış görülmektedir. Proteinlerin su tutma kapasiteleri 4.0$4.6 \mathrm{pH}$ aralığında artmakta, buna bağlı olarak viskozite düzelmekte ve serum ayrılması düşüşe geçmektedir (Rasic ve Kurman, 1978).

$\mathrm{Bu}$ araştırmada süzme yoğurtlarda hesaplanan yağ, $\mathrm{KM}, \mathrm{pH}$ ve renk değerlerine ait sonuçlar, bu konuda yapılan bazı çalışmanlar ile uyumluluk gösterirken (Kırdar ve Gün, 2001; Gökçe ve ark., 2001), özelikle KM ve yağ oranı açısından bu çalışmada daha yüksek oranlar kaydedilmiştir. Renk ölçümlerinde $L^{*}$ değeri parlaklığı ifade ederken $\left(L^{*}=0\right.$ siyah ve $L^{*}=100$ beyaz), c değeri renk (Chroma) değeri olup, $\mathrm{H}$ değeri
10.40 arasında değişmiştir (Gökçe ve ark., 2001). Isparta ve Burdur illerinden toplanan 22 adet süzme yoğurt örneğinde yapılan başka bir araştırmada, KM $\% 17.84-27.72$, yağ \%2.00-7.45, titrasyon asitliği \% $0.78-2.00$ ve $\mathrm{pH} 3.65-4.22$ arasında bulunmuştur. Çalışmada renk ölçümlerinde $L$ değeri $91.97, a^{*}$ deģeri -2.10 ve $b^{*}$ değeri 8.16 olarak belirlenmiştir (Şimşek ve ark., 2010). Farklı asitliklerdeki yoğurtlardan torba yoğurt üretimi şeklinde yapılan bir araştırmada, torba yoğurtlardaki asitliğin önemli derecede etkilendiği $(P<0.05)$ görülmüş, torba yoğurtlarda ortalama $\mathrm{pH}$ değeri 3.60, KM \% 17.24 ve yağ \% 5.08 olarak hesaplanmıştır (Şahan ve ark., 2004).

Atamer ve ark. (1988), Ankara'da tüketime sunulan süzme yoğurtlarda yaptıkları çalışmada, 2 örnekte ortalama toplam KM yi \%19.41 \pm 3.12 , yağ değerini \% $2.54 \pm 2,54, \mathrm{pH}$ 'уı $3.52 \pm 0.13$ ve titrasyon asitliğini ise $\% 2.26 \pm 0.25$ süt asidi olarak belirlemişlerdir. Torba (süzme) yoğurt üretiminde yapılan bir başka araştırmada, KM içerikleri \%12.75, \%14.06 ve \%15.50 olan yoğurtlardan üretilen torba yoğurtlarda KM oranları sırasıyla \%24.67, \%23.11 ve \%22.58; yağ oranları \% $8.15, \% 7.5$ ve $\% 8.84$ olarak bulunmuştur (Atamer ve ark., 1990). Kırklareli ve civarında üretilen 26 adet yoğurt örneğinin bazı fizikokimyasal ve mikrobiyolojik 
özellikleri belirlenerek Türk Gıda Kodeksi'ne uygunluğu açısından değerlendirildiği bir araştırmada ise, yoğurt örneklerinin $\mathrm{pH}$ değeri 3.90-5.25, laktik asit cinsinden asitlik değeri \%0.10-1.88 arasında bulunmuştur (Çetin ve ark., 2014). Konya ilinde yapılan diğer bir araştırmada, 45 adet süzme yoğurt numunesi incelenmiş ve numunelerde $\mathrm{KM}$, yağ ve laktik sit cinsinde asitlik değerleri sırası ile \% 19.06-\%32.04, \% $7.00-\% 16.2$ ve $1.53-2.25$ aralığında bulunmuştur (Tekinşen ve ark., 2008).

Erzurum ilinde rastgele olarak alınan 13 adet torba yoğurdu üzerinde yapılan bir araştırmada ortalama değerler olarak KM \%32.36 ve yağ oranı \%7.58 olarak bulunmuştur (Çağlar ve Ceylan, 1997). Afyonkarahisar ili halk pazarlarında satışa sunulan konsantre yoğurtlarda yapılan çalışmada, süzme yoğurt örneklerinde $\mathrm{pH} 3.51 \pm 0.36$, titrasyon asitliği \%2.09 \pm 0.11 , yağ $\% 5.36 \pm 0.14, \mathrm{KM} \% 23.88 \pm 2.17$ ve protein $\%$ $6.14 \pm 1.08$ olarak bulunmuştur (Akarca ve Tomar, 2019).

Düzenli yoğurt tüketimi, yetişkinlerde immün (bağışıkıı) sistemini güçlendirmektedir. Bu etki, asidik bir ürün olan yoğurdun, bağırsaklarda asitliği artırmasına paralel olarak zararlı mikroorganizmaların gelişimini inhibe etmesi ve yoğurt bakterilerinin bağırsak çeperlerine tutunarak ortama hâkim olmaları şeklinde açıklanmaktadır (Kırdar ve Gün, 2007).

İnkübasyon çıkış asitliği ve buna bağlı olarak inkübasyon süresi yoğurt üretiminin en önemli işlem basamaklarından birisidir. Bu bağlamda inkübasyon parametrelerinin seçimi önem kazanmaktadır. pH 4.2 -4.6 arasında yoğurdun su tutma kapasitesi optimum olduğundan, üretimde $\mathrm{pH}$ 4.5-4.6 dolayına geldiğinde inkübasyona son verilmektedir. İnkübasyonda ilk önce L. bulgaricus üremeye başlar ve bu bakterinin proteolitik enzim aktivitesi $S$. thermophilus'a göre daha yüksektir. Üremek için kazein, $\mathrm{H}_{2} \mathrm{~S}$ ve formiat kullanır ve kükürtlü aminoasitleri üretir. $43^{\circ} \mathrm{C}$ 'de $S$. thermophilus kükürtlü amioasitleri kullanarak üremeye başlar. Yaklaşık 2 saat sonunda, starter kültürlerin oluşturduğu laktik asit nedeni ile $\mathrm{pH}$ 5.2-5.3 seviyesine düşer. Kazeinat partiküllerinin stabilizasyonu bu aşamada bozulur. Kalsiyum ve fosfat, kazein kompleksinden yavaş yavaş ayrılır ve iyonize duruma geçer. Bu aşama ilk pıhtının oluştuğu aşama olup $\mathrm{pH}$ 4.6' da her iki bakterinin düzeyi eşitlenir (Özer, 2006; Vedamuthu, 2006). Bu çalışmanın önemli bir yanı, süzme yoğurt üretimlerinin üniversite bünyesindeki uygulama biriminde kontrollü olarak yapılmasıdır. Üretimde inkübasyon süresi iyi ayarlanmadığı takdirde beklenen kalite, randıman ve yapıda yoğurt elde edilemez. Bu araştırmada inkübasyon asitliğinin ve buna bağlı olarak sürenin, inkübasyon çıkış asitliğinden etkilendiği görülmektedir. Dolayısıyla pH'nın 4.40 veya 4.20 olarak ayarlanması ve inkübasyonun bu şeklide bitirilmesi işletmeler için daha ekonomik ve avantajlı olacaktır.
Araştırmada elde edilen bulgular ile aynı konuda yapılan benzer çalışmalar (Atamer ve ark., 1988; Çağlar ve ark., 1997; Gökçe ve ark., 2001) arasında farklılıklar bulunmaktadır. Farklılıklar; hammadde olarak kullanılan çiğ sütün kalitesinden, çiğ süte uygulanan proseslerden, yararlanılan starter kültürün tipi ve oranından, elde edilen ürünün fiziksel ve kimyasal özelliklerinden kaynaklanmaktadır. İlaveten depolama, ambalajlama, nakliye ve satış aşamalarındaki uygulamalarda bu anlamda etkilidir. Türk Gıda Kodeksi Fermente Süt Ürünleri Tebliğinde ilgili kısımda yoğurtlarda yağ oranı en az \%3.8 ve yağsız KM oranı ağırlıkça en az \%12 olarak belirtilmektedir (Anonim, 2009b).

Sonuç olarak, taze yoğurtta inkübasyon çıkış pH'sının değiştirilmesi, elde edilen süzme yoğurt özelliklerinde bir takım etkiler yaratmıştır. Bu anlamda inkübasyon çıkış pH'sının 4.40 değerinden 4.00' a düşürülmesi, özelikle süzme yoğurt randımanında azalmaya, süzme yoğurt suyu miktarında artışa ve inkübasyon süresinde uzamaya sebep olmuştur. İşletmelerde yapılacak olan planlama ile taze yoğurtta inkübasyonun $\mathrm{pH} 4.40$ veya 4.20 de sonlandırılması, elde edilecek süzme yoğurtların daha ekonomik olarak üretilmesine olanak sağlayacaktır. Illaveten, Türk Gıda Kodeksi Fermente Süt Ürünleri Tebliği'nde özellikle süzme yoğurtta önemli bir kriter olan kuru madde miktarı ile asitlik değerlerinin (\% asitlik, $\mathrm{pH}$ veya $\mathrm{SH}$ ) de yer alması gerekmektedir. Bu değerlerin tebliğde olmamasının, tüketicinin hilelere maruz kalmasına, hile yapmayan firmalara karşı haksız rekabetin oluşmasına ve sonuçta yoğurt kalitesinin bozulmasına yol açacağı düşünülmektedir.

\section{Teşekkür}

$\mathrm{Bu}$ araştırma Aydın Adnan Menderes Üniversitesi, Bilimsel Araştırma Projeleri tarafından ÇMYO-19001 proje numarası ile desteklenmiştir.

\section{Kaynaklar}

Anonim. TS EN ISO 707. Milk and milk products Guidance on sampling quality, 2009a; https:// archive.org/stream/et.iso.707.2012/

et.iso.707.2012_djvu.txt; Erişim Tarihi: 15.03.2020.

Anonim. Türk Gıda Kodeksi, Fermente Süt Ürünleri Tebliği (Tebliğ No: 2009/25). Tarım ve Köy İşleri Bakanlığı, Ankara. 2009b; Resmi Gazete, Sayı: 27143.

Anonim. Dünya ve Türkiye'de Süt Sektör İstatistikleri, Ulusal Süt Konseyi Raporu, 2018; https:// ulusalsutkonseyi.org.tr/wp-content/uploads/ Sut_Raporu_2018_Web_Kapakli.pdf; Erişim Tarihi: 15 Mart 2020.

Anonim. Türk Gıda Kodeksi İçme Sütleri Tebliği (Tebliğ No: 2019/12). Tarım ve Köy İşleri Bakanlığı, 
Ankara, 2019; Resmi Gazete, Sayı: 30699.

Akarca G, Tomar, O. Afyonkarahisar ili semt pazarlarında satılan süzme (kese) yoğurtların kimyasal ve mikrobiyolojik özellikleri. Akademik Gıda 2019; 17 (2): 212-6.

Atamer M, Sezgin E, Yetişemeyen A. Torba yoğurtların bazı niteliklerinin araştırılması. Gıda 1988; 13 (4): 283-8.

Atamer M, Yetişmeyen A, Ergül E, Dağlıoğlu O, Yıldırım M. Torba yoğurdu üretiminde, kurumadde ve bileşenlerinin torbada tutulma ve serumdaki kayıpları üzerine bir araştırma. Gıda 1990; 15(1): 35-9.

Becker T, Puhan Z. Effect of different processes to increase the milk solids non fat content on the rheological properties of yoghurt. Milchwissenschaft 1989; 44: 626-9.

Çağlar A, Ceylan ZG, Kökosmanlı M. Torba yoğurtlarının kimyasal ve mikrobiyolojik özellikleri üzerine bir araştırma. Gıda 1997; 22(3): 209-15.

Çetin B, Atik A, Karasu S. Kırklareli' nde üretilen yoğurt ve ayranların fizikokimyasal ve mikrobiyolojik özellikleri. Akademik Gıda 2014; 12(2): 57-60.

Demirci M, Gündüz HH. Süt Teknoloğunun El Kitabı. Hasad Yayıncılık. Gıda Serisi 1. İstanbul, 2000; s. 191.

Eralp M. Torba Yoğurdu. Ankara: Nur Matbaası, 1991; s. 8.

Gökçe R, Çon AH, Gürsoy O. Denizli'de yaz ve kış mevsimlerinde üretilen torba yoğurtların kimyasal ve mikrobiyolojik kalitesinin araştırılması. Pamukkale Ünv Müh Fak Derg 2001; 7(1): 81-6.

Keskin M, Setlek P, Demir S. Use of color measurement systems in food science and agriculture. International Advanced Researches \& Engineering Congress. November, 16-18, 2017; OsmaniyeTurkey.

Kırdar SS, Gün İ. Burdur' da süzme yoğurt üretimi üzerine bir araştırma. Gıda 2001; 26(2): 99-107.

Kırdar SS, Gün İ. Süzme yoğurt üretiminde elde edilen serumun bazı özellikleri. SDÜ Fen Bil Enst Der 2007; 11(1): 26-8.

Metin M. Süt ve Mamulleri Analiz Yöntemleri, Ege Üniversitesi Yayınları. Rektörlük Yayın No:9. İzmir: Ege Üniversitesi Basımevi, 2012; s. 439.

Özer B. Yoğurt Bilimi ve Teknolojisi. Şanlıurfa; Sidas Medya Ltd Şti, 2006; s. 264-5.
Rasic JL, Kurman JA. Yoghurt, fermented fresh milk products. Copenhagen: Technical Dairy Publishing House, 1978; p.11-3.

Şahan N, Güven M, Kaçar A. Farklı asitliklerdeki yoğurtlardan torba torba yoğurdu üretimi ve netamisinin raf ömrü üzerine etkisi. Gıda 2004; 29(1): 9-15.

Şimşek B, Gün İ, Çelebi M. Isparta yöresinde üretilen süzme yoğurtların protein profilleri ve bunların kimyasal özelliklerle ilişkisi. YYÜ Tar Bil Derg 2010; 20 (3): 208-13.

Tekinşen KK, Nizamlığlu M, Baya, N, Telli N, Köseoğlu İE. Konya'da üretilen süzme (torba) yoğurtların bazı mikrobiyolojik ve kimyasal özellikleri. Vet Bil Derg 2008; 24(1): 69-75.

Terin M, Yavuz F. Türkiye bölgeler arası optimum süt ve ürünleri akışı: Spatial denge modeli. Ege Univ Ziraat Fak Derg 2015; 52(2): 207-17.

Vedamuthu ER. Starter Cultures for Yogurt and Fermented Milks. In RC Chandan Manufacturing Yogurt and Fermented Milks. lowa: Blackwell Publishing, 2006; p. 88-115.

Xrite A. Guide to Understanding Color Communication. Michigan: Xrite, 2007; p. 26.

Yaygın, H. Yoğurt Teknolojisi. Antalya: Akdeniz Ünv Basımevi Yayın No: 75, 1999; s. 331. 